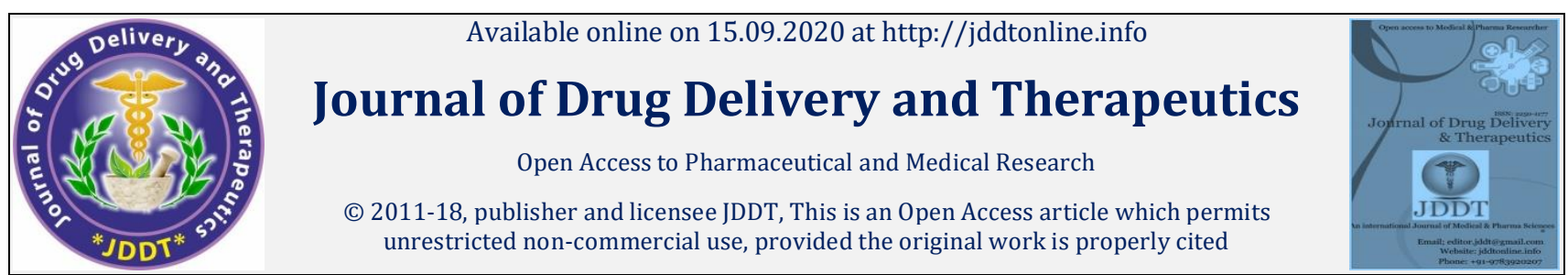

Open 0 Access

Research Article

\title{
Development and Validation of Advanced UV-Spectrophotometric Methods and a RP-HPLC Method for the Simultaneous Estimation of Beclomethasone Dipropionate and Formoterol Fumarate Dihydrate in Bulk and Pharmaceutical Dosage Forms
}

\author{
Mashru Rajashree* and Trivedi Manthan \\ Faculty of Pharmacy, G. H. Patel Building, Donor's Plaza, The Maharaja Sayajirao University of Baroda, Vadodara, Gujarat, India
}

\begin{abstract}
The presented research work aims to develop and validate UV-Spectrophotometric as well as RP-HPLC methods for the simultaneous estimation of Beclomethasone Dipropionate (BDP) and Formoterol Fumarate Dihydrate (FFD). These methods offer a higher degree of sensitivity than the already present methods of analysis. By implementing advanced spectroscopic techniques such as Dual Wavelength Method and First Derivative Spectroscopy it is found that the sensitivity of the methods is increased. The linearity of both the methods was in the range of $10 \mu \mathrm{g} / \mathrm{ml}$ to $50 \mu \mathrm{g} / \mathrm{ml}$ for BDP and $1 \mu \mathrm{g} / \mathrm{ml}$ to $5 \mu \mathrm{g} / \mathrm{ml}$ for FFD, with an $\mathrm{r}^{2}$ value of 0.999 and 0.9988 respectively for Dual Wavelength Method and First Derivative Method. The LOD values of Dual Wavelength Method and First Derivative Method were found to be $0.127 \mu \mathrm{g} / \mathrm{ml}$ and $0.016 \mu \mathrm{g} / \mathrm{ml}$ respectively. A RP-HPLC Method has also been developed and validated for this combination having a linearity in range of $50 \mu \mathrm{g} / \mathrm{ml}$ to $250 \mu \mathrm{g} / \mathrm{ml}$ for BDP and $1.5 \mu \mathrm{g} / \mathrm{ml}$ to $7.5 \mu \mathrm{g} / \mathrm{ml}$ for FFD. The $\mathrm{r}^{2}$ value of BDP and FFD was found to be 0.9995 and 0.994 . The application of this RP-HPLC Method may also be extended for the simultaneous estimation of a triple combination of Beclomethasone Dipropionate, Formoterol Fumarate and Glycopyrronium Bromide (GPB).
\end{abstract}

Keywords: Beclomethasone, Formoterol, Glycopyrrolate, Dual-Wavelength-Method, First-Derivative, Spectroscopy, RP-HPLC

Article Info: Received 05 July 2020; Review Completed 21 Aug 2020; Accepted 27 August 2020; Available online 15 September 2020

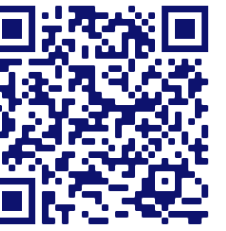

Cite this article as:

Mashru R, Trivedi M, Development and Validation of Advanced UV-Spectrophotometric Methods and a RP-HPLC Method for the Simultaneous Estimation of Beclomethasone Dipropionate and Formoterol Fumarate Dihydrate in Bulk and Pharmaceutical Dosage Forms, Journal of Drug Delivery and Therapeutics. 2020; 10(5):108-117

http://dx.doi.org/10.22270/jddt.v10i5.4382

*Address for Correspondence:

Mashru Rajashree, Faculty of Pharmacy, G. H. Patel Building, Donor's Plaza, The Maharaja Sayajirao University of Baroda, Vadodara, Gujarat, India

\section{INTRODUCTION}

A Combination of Beclomethasone Dipropionate and Formoterol Fumarate Dihydrate is used to treat COPD and other lung disorders. Beclomethasone here as a corticosteroid increases the expression of $\beta 2 \quad-$ adrenoceptors and protects them against down-regulation. Conversely, $\beta 2$ - Adrenergic receptor agonists improve the anti-inflammatory action of corticosteroids. Thus this combination synergistically relaxed human bronchi; the extent of such an interaction is very strong at low-to-medium concentrations in the small airways. ${ }^{1}$

Various methods for the analysis of this combination have already been reported such as; Simultaneous estimation of Beclomethasone Dipropionate and Formoterol Fumarate in Rotacap Dosage form using UV-Spectroscopic Method 2, RP-
HPLC method development and validation of Beclomethasone and Formoterol 3, HPLC determination of Beclomethasone and its degradation products ${ }^{4}$, Comparison of Beclomethasone / Formoterol versus Budesonide / Formoterol combination therapy in asthma. ${ }^{5}$

Beclomethasone Dipropionate is chemically $9 \alpha$-chloro- $11 \beta$ hydroxy-16 $\beta$-methyl-3, 20-dioxopregna-1, 4-diene-17, 21diyldipropionate and Formoterol Fumarate is a dihydrate salt of fumaric acid with (RS)-2'-hydroxy-5'-[(RS)-1hydroxy-2-[[(RS)-p-methoxy- $\alpha$-methylphenethyl] amino] ethyl] formanilide. The structure of Beclomethasone Dipropionate and Formoterol Fumarate are as represented below in Figure 1 and Figure 2. 
<smiles>CCC(=O)OCC(=O)C1(OC(=O)CC)C(C)CC2C3CCC4=CC(=O)C=CC4(C)C3(Cl)C(O)CC21C</smiles>

Figure 1: Structure of Beclomethasone Dipropionate

\section{MATERIALS AND METHOD}

\section{Instruments / Apparatus / Softwares:}

Shimadzu HPLC System equipped with UV Detector, UVVisible Spectrophotometer, $\mathrm{pH}$ meter and electronic balance.

\section{Chromatographic Condition for RP-HPLC:}

ANALYTICAL - $\mathrm{C}_{18}$ HyperChrome ODS-BP Column was used having dimensions of $250 \mathrm{~mm} \times 6 \mathrm{~mm}$, and an internal diameter of $5 \mu \mathrm{m}$. The optimized mobile phase used was ACN: Ammonium Acetate Buffer (70:30). A flow rate of 1 $\mathrm{ml} / \mathrm{min}$ was set and the wavelength of detection was set to $218 \mathrm{~nm}$ for the detection of BDP and FFD, whereas for the detection of the triple combination of BDP, FFD and GPB the wavelength used was $252 \mathrm{~nm}$. A fixed injection volume of $20 \mu \mathrm{L}$ was taken each time and the run time was set to 15 minutes.

\section{Preparation of Standard Stock Solution:}

For UV-Spectroscopic methods, the standard stock solutions of BDP as well as FFD are prepared by taking $10 \mathrm{mg}$ of the standard drug in $10 \mathrm{ml}$ Methanol to get a concentration of $1000 \mu \mathrm{g} / \mathrm{ml}$.

For RP-HPLC Method, weigh accurately an amount of $10 \mathrm{mg}$ of Beclomethasone Dipropionate and transfer it into a previously calibrated volumetric flask. The volume is made up to the mark using the mobile phase itself. Similarly weigh accurately an amount of 10mg of Formoterol Fumarate and transfer it into a previously calibrated volumetric flask. The volume is made up to the mark using the mobile phase itself.

\section{Preparation of working standard solution:}

For UV-Spectroscopic methods, the working stock solution of BDP is prepared by taking $2 \mathrm{ml}$ of the standard stock solution and transferring it to a $10 \mathrm{ml}$ volumetric flask. The volume is made up to the mark using Methanol to get a concentration of $200 \mu \mathrm{g} / \mathrm{ml}$. Similarly the working standard solution of FFD is prepared by taking $1 \mathrm{ml}$ of the standard stock solution and transferring it to a $10 \mathrm{ml}$ volumetric flask. The volume is made up to the mark using Methanol to get a concentration of $100 \mu \mathrm{g} / \mathrm{ml}$.

For RP-HPLC Method the working standard solution of BDP is the Standard Stock Solution itself, whereas for FFD the working standard solution must be prepared. The Working Standard Solution of FFD is prepared by taking $1 \mathrm{ml}$ of the Standard Stock solution and diluting this solution up to $10 \mathrm{ml}$ using the mobile phase.

\section{Derivative Spectroscopy:}

Derivative Spectroscopy involves the conversion of a normal spectrum (fundamental, zero-order spectrum) to its first, second or higher derivative spectra by differentiating absorbance of the sample with respect to wavelength $(\lambda)$. The differentiation of zero-order spectrum can lead to separation of overlapped signals, elimination of background<smiles>COc1ccc(CC(C)NCC(O)c2ccc(O)c(NC=O)c2)cc1</smiles>

Figure 2: Structure of Formoterol Fumarate

caused by presence of other compounds in a sample, improvement of resolution of mixtures as it enhances the detectability of minor spectral features, and enhancement of sensitivity and specificity. 6

\section{Dual Wavelength Method:}

Dual wavelength method also known as two wavelengths method, facilitates analyzing a component in presence of an interfering component by measuring the absorbance difference $(\Delta \mathrm{A})$ between two points in the mixture spectrum. In this method one of the drugs is considered as a component of interest and the other drug is considered as an interfering component and vice-versa. The basis for such method is the selection of two wavelengths where the interfering component shows the same absorbance $(\Delta \mathrm{A}$ equals zero) whereas the component of interest shows significant difference in absorbance with concentration. $\Delta \mathrm{A}$ between two points on the mixture spectra is directly proportional to the concentration of the component of interest independent of interfering component. 6

\section{Method Validation Parameters: 7}

The developed UV-Spectroscopic and RP-HPLC methods were validated in accordance with the current ICH guidelines - Q2 (R1). The parameters which were validated include Specificity, Linearity, Range, Limit of detection, Limit of quantification, Precision, Accuracy, Ruggedness, Robustness as well as system suitability tests for RP-HPLC.

\section{Specificity:}

Specificity is one of the first validation parameters that need to be studied. It represents the ability of the analytical method to generate signals which are free from interferences. It is the capability of the method to estimate precisely an analyte in the presence of interferences that may be expected to be present in the sample. Typically these interferences may be degradants, matrix or impurities present in the sample. Identification tests should be able to differentiate the compound of closely related structures which are expected to be present.

\section{Linearity and Range:}

Linearity of an analytical method represents that there is a linear relationship between the signal and the concentration of the analyte under investigation. Linearity should be evaluated by visual inspection of a plot of signals as a function of the analyte concentration or content. If there is a linear relationship, test results should be evaluated by appropriate statistical methods, for example, by calculation of a regression line by the method of least squares. It can be analyzed by performing single measurements at several different analyte concentrations. The data is then processed using a linear least square regression method. The resulting plot gives us the intercept, slope and correlation coefficient values which is able to provide the desired information on the linearity of the method. 


\section{Precision:}

The precision of an analytical method represents the closeness of individual measurements to each other under similar analytical condition and it is divided in three categories. The ICH guideline - Q2(R1) suggest that repeatability should be assessed using a minimum of 9 determination covering the specified range for the procedure (3 concentrations / 3replicates each) or a minimum of 6 determinations at $100 \%$ of the test concentration.

- Intra-day Precision: It can be defined as within-day precision and performed by 3 replicates at 3 different concentrations.

- Inter-day Precision: It can also be referred to as between-day precision. It is determined by 3 replicates at 3 different concentrations.

- Repeatability: Precision which is measured keeping the same analyst and same operating condition over short period of time?

\section{Accuracy:}

Accuracy is defined as a measure of closeness of agreement between the experimental value and the accepted reference value. It is one of the most important parameters which is to be considered in the validation of an analytical method. It can also be defined as the percent recovery of known amounts of standard drug added to a sample. There are three way to determine accuracy:

- Recovery of analyte spiked into blank matrix

- Comparison to a reference standard

- Standard addition of the analyte

\section{Limit of Detection (LOD):}

Limit of detection is determined by the analysis of samples with known concentration of drug and by establishing that minimum level at which the analyte can detected, but not necessarily quantitated as a precise value. LOD is generally expressed in terms of concentration of analyte in the sample. A number of approaches may be applied according to the ICH for determination of the detection limit of a sample depending on the nature of the analyte, suitability of the method and instrument which is used for analysis. The acceptable approaches are Signal to noise ratio, Standard deviation of the slope of the linearity plot, Visual evaluation, Standard deviation of the response.

The formula for calculating the LOD is:

$$
\mathrm{LOD}=\frac{3.3 \sigma}{\mathrm{S}}
$$

Where, $\sigma=$ the standard deviation of the responses

$\mathrm{S}=$ the slope of the calibration curve

\section{Limit of Quantification (LOQ):}

Limit of quantification is defined as the least amount of concentration of the analyte in a sample which can be estimated with appropriate accuracy and precision under the affirmed experimental conditions.

The formula for calculating LOQ is:

$$
\mathrm{LOQ}=\frac{10 \sigma}{\mathrm{S}}
$$

Where, $\sigma=$ the standard deviation of the responses
$\mathrm{S}=$ the slope of the calibration curve

\section{Robustness:}

Robustness of an analytical method can be defined as the ability of the analytical method to remain unaffected by small but deliberate variation in the critical method parameters. The capability to reproduce the results of the analytical method under different circumstances without the occurrence of unforeseen differences is known as robustness. The method parameters which may be varied in RP-HPLC Method include $\mathrm{pH}$, flow rate, column temperature, mobile phase composition, solvents grades, detection wavelength and percentage ACN.

\section{System Suitability Tests (SST):}

These tests are to prove that the system is working ideally before the analysis on the HPLC analyser is carried out. SSTs are required to be done before every sample analysis. The System Suitability Testing (SST) limits should confirm to the guidelines provided by the Center for Drug Evaluation and Research (CDER) as well as the International Conference on Harmonization (ICH). The parameters which are needed to be checked in SST are retention time, theoretical plate number, tailing factor, column efficiency, signal-to-noise ratio and resolution.

\section{RESULTS AND DISCUSSION}

\section{Linearity:}

In each of the developed methods 4 sets of calibration curves were plotted between the absorbance and concentration (in case of UV-Spectrophotometric Methods), or area and concentration (in case of RP-HPLC Method). The Calibration Curve that showed the best $\mathrm{r}^{2}$ values is represented below in Figure 3-6 for each of the four methods. The linearity of First order derivative spectroscopy was taken by first taking the zero order spectra of both drugs individually in the range of 200-400nm (Figure 3), and then converting them to the first derivative spectra. The transformation of zero order spectra to first derivative spectra was done in the software using a $\Delta \lambda=5 \mathrm{~nm}$ and scaling factor of 20 . Thus, here at 239nm (Zero Crossing Point of BDP) the estimation of FFD is possible, whereas at $268.4 \mathrm{~nm}$ (Zero Crossing Point of FFD) the estimation of BDP is done as shown in Figure 4. The linearity of the First Order Derivative Method was found in the range of $10 \mu \mathrm{g} / \mathrm{ml}$ to $50 \mu \mathrm{g} / \mathrm{ml}$ for BDP ( $\left.\mathrm{r}^{2}=0.9992\right)$ and $1 \mu \mathrm{g} / \mathrm{ml}$ to $5 \mu \mathrm{g} / \mathrm{ml}$ for FFD $\left(\mathrm{r}^{2}=0.9989\right)$.

In case of Dual wavelength method at $215 \mathrm{~nm}$ and $266 \mathrm{~nm}$ the absorbance values of BDP are the same, but the absorbance values of FFD at these two wavelengths are different. This difference may be used for the quantification of FFD. Similarly at wavelengths $259 \mathrm{~nm}$ and $284 \mathrm{~nm}$ the absorbance values of FFD are the same, but the absorbance values of BDP at these two wavelengths are different. This difference may be used for the quantification of BDP. The linearity as shown in Figure 5 of Dual Wavelength Method was found in the range of $10 \mu \mathrm{g} / \mathrm{ml}$ to $50 \mu \mathrm{g} / \mathrm{ml}$ for BDP $\left(\mathrm{r}^{2}=0.999\right)$ and 1 $\mu \mathrm{g} / \mathrm{ml}$ to $5 \mu \mathrm{g} / \mathrm{ml}$ for FFD $\left(\mathrm{r}^{2}=0.9988\right)$.

The linearity of the developed RP-HPLC Method of BDP and FFD was established using the optimized mobile phase of ACN: Ammonium Acetate Buffer with a pH set to 4.5 as shown in Figure 6. The concentration range in which the beer-lambert law was followed was found to be $50 \mu \mathrm{g} / \mathrm{ml}$ to $250 \mu \mathrm{g} / \mathrm{ml}$ for BDP and $1.5 \mu \mathrm{g} / \mathrm{ml}$ to $7.5 \mu \mathrm{g} / \mathrm{ml}$ for FFD. The $\mathrm{r}^{2}$ value of RP-HPLC linearity was found to be 0.9995 for BDP and 0.9994 for FFD. 


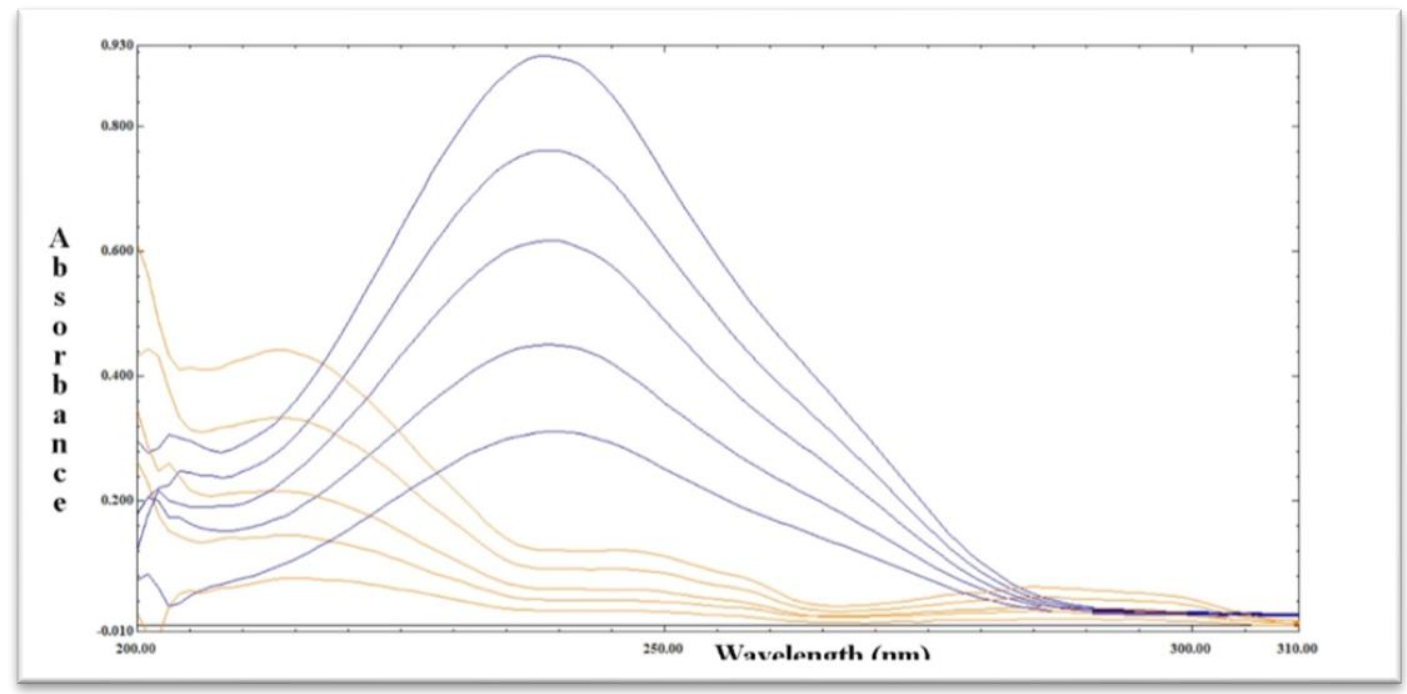

Figure 3: Zero order overlay of BDP and FFD

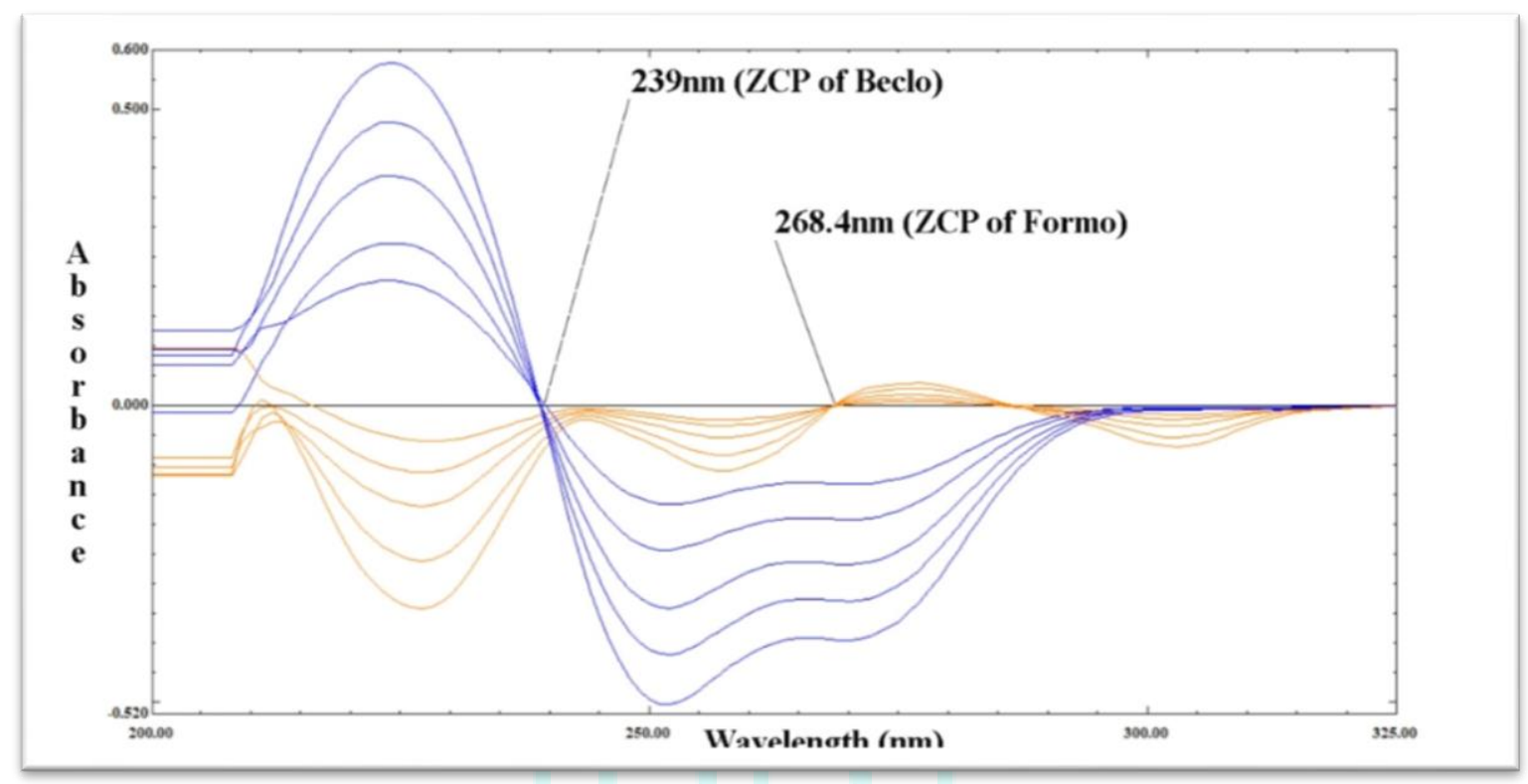

Figure 4: First Derivative overlay spectra of BDP and FFD

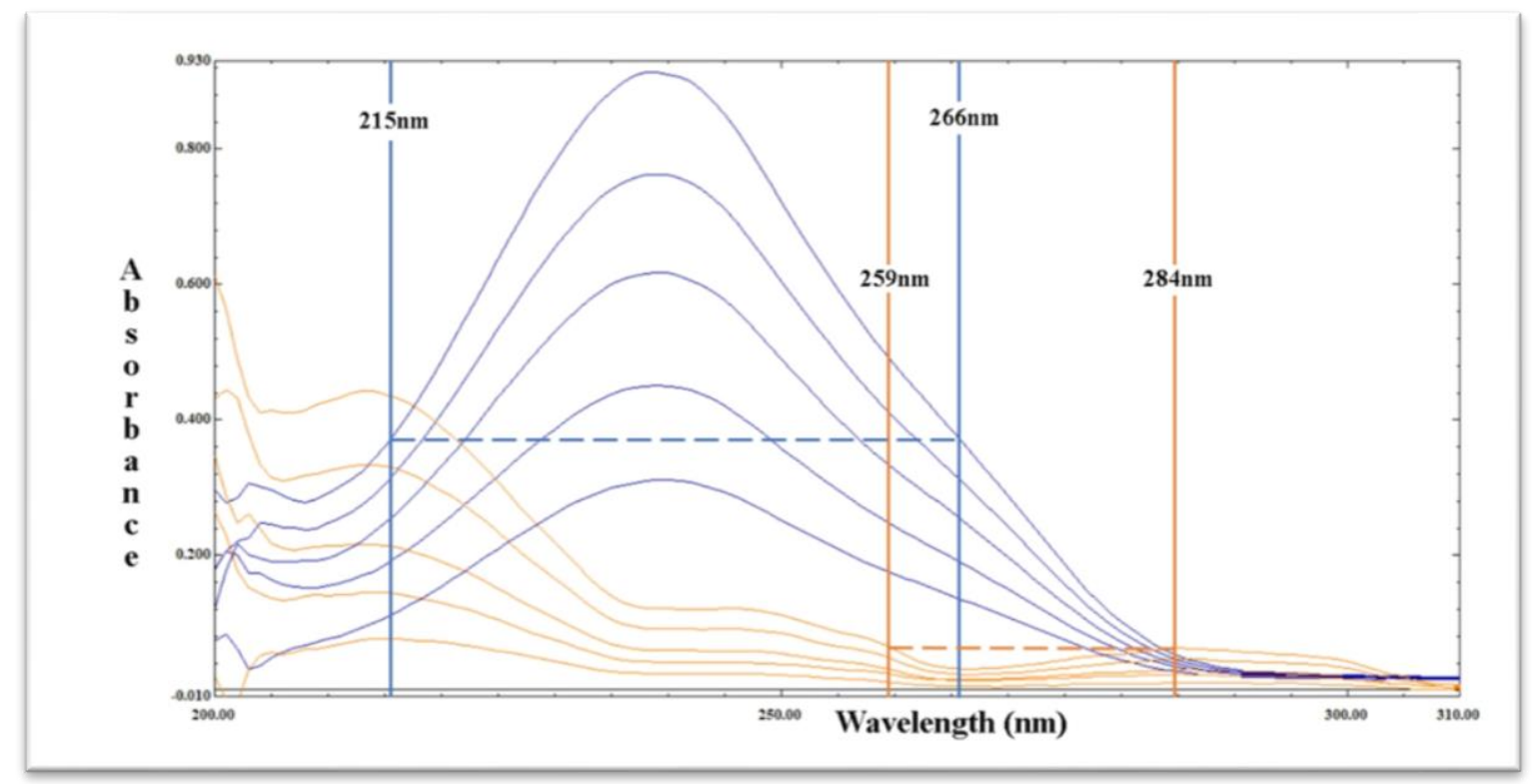

Figure 5: Dual Wavelength Spectra of BDP and FFD 


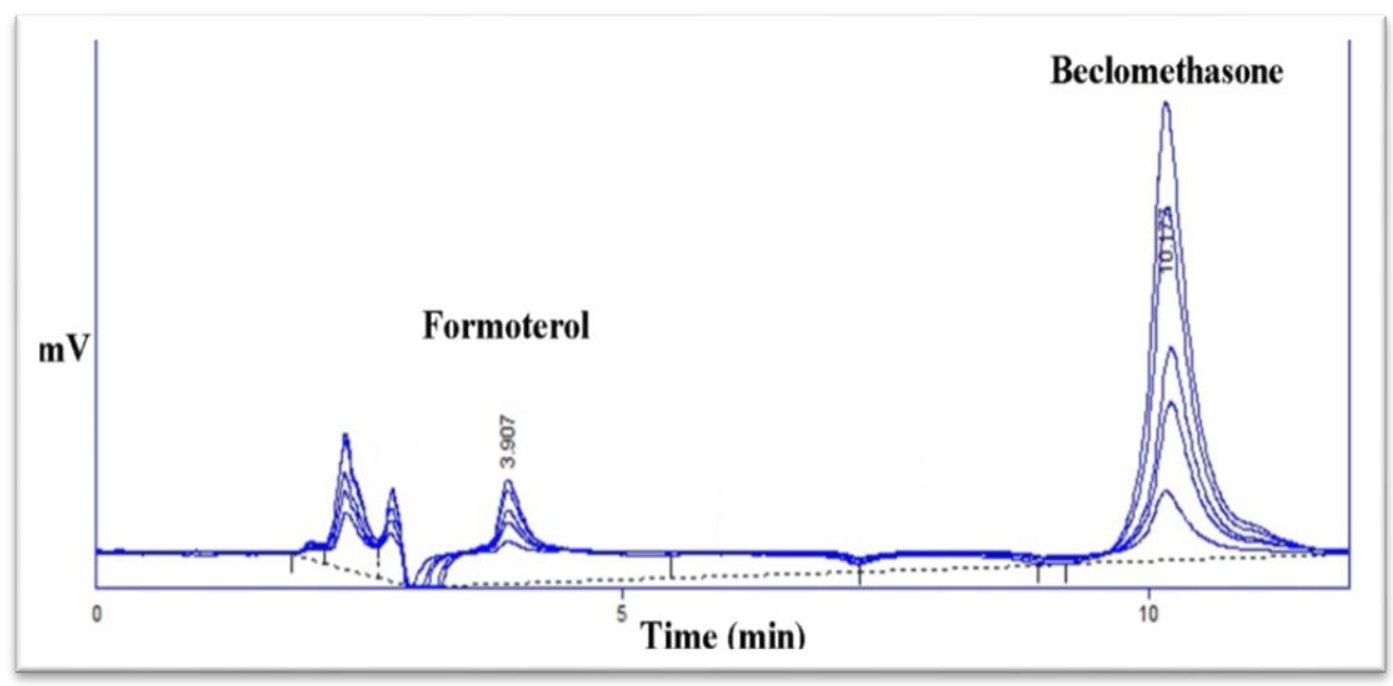

Figure 6: RP-HPLC Overlay for BDP and FFD

\section{Limit of Detection and Limit of Quantification:}

The Limit of Detection and Limit of Quantification was calculated using the above formulas and the data is represented in Table 1 below.

Table 1: Limit of Detection and Limit of Quantification of BDP and FFD

\begin{tabular}{|c|c|c|c|c|c|c|}
\hline \multirow{2}{*}{ Drug } & \multicolumn{3}{|c|}{ Limit of Detection (LOD) } & \multicolumn{3}{c|}{ Limit of Quantification (LOQ) } \\
\cline { 2 - 7 } & $\begin{array}{c}\text { First } \\
\text { Derivative } \\
\text { Method }\end{array}$ & $\begin{array}{c}\text { Dual } \\
\text { Wavelength } \\
\text { Method }\end{array}$ & $\begin{array}{c}\text { RP - HPLC } \\
\text { Method }\end{array}$ & $\begin{array}{c}\text { First Derivative } \\
\text { Method }\end{array}$ & $\begin{array}{c}\text { Dual } \\
\text { Wavelength } \\
\text { Method }\end{array}$ & $\begin{array}{c}\text { RP - HPLC } \\
\text { Method }\end{array}$ \\
\hline BDP & $0.739 \mu \mathrm{g} / \mathrm{ml}$ & $0.127 \mu \mathrm{g} / \mathrm{ml}$ & $3.283 \mu \mathrm{g} / \mathrm{ml}$ & $2.240 \mu \mathrm{g} / \mathrm{ml}$ & $0.384 \mu \mathrm{g} / \mathrm{ml}$ & $9.951 \mu \mathrm{g} / \mathrm{ml}$ \\
\hline FFD & $0.183 \mu \mathrm{g} / \mathrm{ml}$ & $0.016 \mu \mathrm{g} / \mathrm{ml}$ & $0.081 \mu \mathrm{g} / \mathrm{ml}$ & $0.556 \mu \mathrm{g} / \mathrm{ml}$ & $0.049 \mu \mathrm{g} / \mathrm{ml}$ & $0.248 \mu \mathrm{g} / \mathrm{ml}$ \\
\hline
\end{tabular}

\section{Precision:}

The precision of an analytical method expresses the closeness of agreement between a series of measurements which are obtained by performing multiple samplings of the same homogenous sample under the given conditions of the method.

In this research paper, various methods have been analysed for precision at two levels:

1. Repeatability (precision under the same operating conditions over a short interval of time)

2. Intermediate precision (variations in the results obtained at different intervals)
From the results of precision it may be concluded that both the methods developed are precise as the \%RSD values are less than 2. It also may be concluded here that the Dual Wavelength Method is more precise than the $1^{\text {st }}$ Derivative Method.

In the data represented below Table 2 represents the repeatability data, whereas Table 3 and Table 4 present the data for intra-day and inter-day precision respectively. Precision data are represented in terms of \%RSD and the nominal concentration of Beclomethasone Dipropionate (BDP) and Formoterol Fumarate Dihydrate (FFD) was kept $50 \mu \mathrm{g} / \mathrm{ml}$ and $1.5 \mu \mathrm{g} / \mathrm{ml}$ respectively for UVSpectrophotometric Methods and $200 \mu \mathrm{g} / \mathrm{ml}$ (BDP), $6 \mu \mathrm{g} / \mathrm{ml}$ (FFD) for RP-HPLC Method.

Table 2: Repeatability data expressed in terms of \% RSD

\begin{tabular}{|c|c|c|c|c|c|c|c|}
\hline \multicolumn{9}{|c|}{ Repeatability } \\
\hline \multicolumn{3}{|c|}{ Beclomethasone } & \multicolumn{4}{c|}{ Formoterol } \\
\hline Parameter & 1 st Der. & DWM & RP-HPLC & Parameter & 1st Der. & DWM & RP-HPLC \\
\hline Mean & 0.396 & 0.446 & 2343.452 & Mean & 0.020 & 0.081 & 183.422 \\
\hline SD & 0.00173 & 0.00057 & 11.82 & SD & 0.00037 & 0.00074 & 1.794 \\
\hline \% RSD & $\mathbf{0 . 4 3 7}$ & $\mathbf{0 . 2 3 9}$ & $\mathbf{0 . 5 0 4}$ & $\mathbf{\% ~ R S D ~}$ & $\mathbf{1 . 7 8 8}$ & $\mathbf{0 . 9 1 2}$ & $\mathbf{0 . 9 7 8}$ \\
\hline
\end{tabular}


Table 3: Intra-day data expressed in terms of \% RSD

\begin{tabular}{|c|c|c|c|c|c|c|c|}
\hline \multicolumn{9}{|c|}{ Intra-Day Precision } \\
\hline \multicolumn{3}{|c|}{ Beclomethasone } & \multicolumn{4}{c|}{ Formoterol } \\
\hline Parameter & 1 st Der. & DWM & RP-HPLC & Parameter & 1st Der. & DWM & RP-HPLC \\
\hline Mean & 0.396 & 0.0603 & 2351.307 & Mean & 0.0208 & 0.0818 & 182.598 \\
\hline SD & 0.00221 & 0.00047 & 7.33 & SD & 0.00037 & 0.00068 & 2.54 \\
\hline \% RSD & $\mathbf{0 . 5 5 9}$ & $\mathbf{0 . 3 8 2}$ & $\mathbf{0 . 3 1 1}$ & $\mathbf{\%}$ RSD & $\mathbf{1 . 7 8 8}$ & $\mathbf{0 . 8 3 9}$ & $\mathbf{1 . 3 9 4}$ \\
\hline
\end{tabular}

Table 4: Inter-day data expressed in terms of \% RSD

\begin{tabular}{|c|c|c|c|c|c|c|c|}
\hline \multicolumn{9}{|c|}{ Inter-Day Precision } \\
\hline \multicolumn{3}{|c|}{ Beclomethasone } & \multicolumn{4}{c|}{ Formoterol } \\
\hline Parameter & 1 st Der. & DWM & RP-HPLC & Parameter & 1 st Der. & DWM & RP-HPLC \\
\hline Mean & 0.395 & 0.06 & 2347.635 & Mean & 0.0208 & 0.0808 & 183.654 \\
\hline SD & 0.00197 & 0.00037 & 17.05 & SD & 0.00037 & 0.00068 & 1.8 \\
\hline \% RSD & $\mathbf{0 . 4 9 8}$ & $\mathbf{0 . 6 1 9}$ & $\mathbf{0 . 7 2 6}$ & $\mathbf{\% ~ R S D ~}$ & $\mathbf{1 . 7 8 8}$ & $\mathbf{0 . 8 5}$ & $\mathbf{0 . 9 8 4}$ \\
\hline
\end{tabular}

\section{Accuracy:}

Recovery studies for the UV-Spectrophotometric methods were conducted using the Standard Addition Method by taking a nominal concentration of $20 \mu \mathrm{g} / \mathrm{ml}$ for Beclomethasone Dipropionate and $0.6 \mu \mathrm{g} / \mathrm{ml}$ for Formoterol Fumarate Dihydrate from the formulation (test sample) and then spiking this solution by $80 \%, 100 \%$ and $120 \%$ of standard drug (API).

It can be inferred from the presented data that all the developed methods are accurate according to the ICH
Guidelines. It can also be concluded here that the Dual Wavelength Method (presented in Table 6) is more accurate than the $1^{\text {st }}$ Derivative ZCP Method (presented in Table 5) as the values of \% Recovery are closer to $100 \%$.

The recovery studies of the RP-HPLC Method were also carried out using the Standard Addition Method wherein the nominal concentration of BDP was $100 \mu \mathrm{g} / \mathrm{ml}$, and FFD was $3 \mu \mathrm{g} / \mathrm{ml}$. The accuracy data of this method is represented in Table 7 below.

Table 5: Accuracy of First Derivative Method expressed in terms of \% Recovery

\begin{tabular}{|c|c|c|c|c|c|}
\hline \multicolumn{5}{|c|}{ Feclomethasone Dipropionate } \\
\hline $\begin{array}{c}\text { Sr. } \\
\text { No. }\end{array}$ & $\%$ Spiked & Conc. Of Test & $\begin{array}{c}\text { Standard Conc. } \\
\text { Added }\end{array}$ & $\begin{array}{c}\text { Conc. } \\
\text { Recovered }\end{array}$ & \%Recovery \pm SD (n=3) \\
\hline 1 & 80 & $20 \mu \mathrm{g} / \mathrm{ml}$ & $16 \mu \mathrm{g} / \mathrm{ml}$ & $35.84 \mu \mathrm{g} / \mathrm{ml}$ & $99.557 \pm 0.00205$ \\
\hline 2 & 100 & $20 \mu \mathrm{g} / \mathrm{ml}$ & $20 \mu \mathrm{g} / \mathrm{ml}$ & $39.71 \mu \mathrm{g} / \mathrm{ml}$ & $99.286 \pm 0.00205$ \\
\hline 3 & 120 & $20 \mu \mathrm{g} / \mathrm{ml}$ & $24 \mu \mathrm{g} / \mathrm{ml}$ & $43.61 \mu \mathrm{g} / \mathrm{ml}$ & $99.132 \pm 0.00205$ \\
\hline & & Formoterol Fumarate Dihydrate & \%Recovery \pm SD (n=3) \\
\hline Sr. & $\%$ Spiked & Conc. Of Test & $\begin{array}{c}\text { Standard Conc. } \\
\text { Added }\end{array}$ & $\begin{array}{c}\text { Conc. } \\
\text { Recovered }\end{array}$ & 100.222 \\
\hline 1 & 80 & $0.6 \mu \mathrm{g} / \mathrm{ml}$ & $0.48 \mu \mathrm{g} / \mathrm{ml}$ & $1.05 \mu \mathrm{g} / \mathrm{ml}$ & 99.323 \\
\hline 2 & 100 & $0.6 \mu \mathrm{g} / \mathrm{ml}$ & $0.6 \mu \mathrm{g} / \mathrm{ml}$ & $1.16 \mu \mathrm{g} / \mathrm{ml}$ & 99.932 \\
\hline 3 & 120 & $0.6 \mu \mathrm{g} / \mathrm{ml}$ & $0.72 \mu \mathrm{g} / \mathrm{ml}$ & $1.29 \mu \mathrm{g} / \mathrm{ml}$ & (n) \\
\hline
\end{tabular}


Table 6: Accuracy of Dual Wavelength Method expressed in terms of \% Recovery

\begin{tabular}{|c|c|c|c|c|c|}
\hline \multicolumn{5}{|c|}{ Dual Wavelength Method } \\
\hline \multicolumn{7}{|c|}{ Beclomethasone Dipropionate } \\
\hline $\begin{array}{c}\text { Sr. } \\
\text { No. }\end{array}$ & $\%$ Spiked & Conc. Of Test & $\begin{array}{c}\text { Standard Conc. } \\
\text { Added }\end{array}$ & $\begin{array}{c}\text { Conc. } \\
\text { Recovered }\end{array}$ & \%Recovery \pm SD (n=3) \\
\hline 1 & 80 & $20 \mu \mathrm{g} / \mathrm{ml}$ & $16 \mu \mathrm{g} / \mathrm{ml}$ & $35.83 \mu \mathrm{g} / \mathrm{ml}$ & $99.541 \pm 0.000471$ \\
\hline 2 & 100 & $20 \mu \mathrm{g} / \mathrm{ml}$ & $20 \mu \mathrm{g} / \mathrm{ml}$ & $39.76 \mu \mathrm{g} / \mathrm{ml}$ & $99.416 \pm 0.000471$ \\
\hline 3 & 120 & $20 \mu \mathrm{g} / \mathrm{ml}$ & $24 \mu \mathrm{g} / \mathrm{ml}$ & $43.73 \mu \mathrm{g} / \mathrm{ml}$ & $99.393 \pm 0.000471$ \\
\hline \multicolumn{7}{|c|}{} & & Formoterol Fumarate Dihydrate & \\
\hline Sr. & $\%$ Spiked & Conc. Of Test & $\begin{array}{c}\text { Standard Conc. } \\
\text { Added }\end{array}$ & $\begin{array}{c}\text { Conc. } \\
\text { Recovered }\end{array}$ & \%Recovery \pm SD (n=3) \\
\hline 1 & 80 & $0.6 \mu \mathrm{g} / \mathrm{ml}$ & $0.48 \mu \mathrm{g} / \mathrm{ml}$ & $1.08 \mu \mathrm{g} / \mathrm{ml}$ & $100.374 \pm 0.000471$ \\
\hline 2 & 100 & $0.6 \mu \mathrm{g} / \mathrm{ml}$ & $0.6 \mu \mathrm{g} / \mathrm{ml}$ & $1.19 \mu \mathrm{g} / \mathrm{ml}$ & $99.807 \pm 0.000471$ \\
\hline 3 & 120 & $0.6 \mu \mathrm{g} / \mathrm{ml}$ & $0.72 \mu \mathrm{g} / \mathrm{ml}$ & $1.31 \mu \mathrm{g} / \mathrm{ml}$ & $99.929 \pm 0.000471$ \\
\hline
\end{tabular}

Table 7: Accuracy of RP-HPLC Method expressed in terms of \% Recovery

\begin{tabular}{|c|c|c|c|c|c|}
\hline \multicolumn{5}{|c|}{ Reclomethasone Dipropionate } \\
\hline $\begin{array}{c}|c| \\
\text { Sr. HPLC Method } \\
\text { No. }\end{array}$ & $\%$ Spiked & Conc. Of Test & $\begin{array}{c}\text { Standard Conc. } \\
\text { Added }\end{array}$ & Total Conc. & \%Recovery \pm SD (n=3) \\
\hline 1 & 80 & $100 \mu \mathrm{g} / \mathrm{ml}$ & $80 \mu \mathrm{g} / \mathrm{ml}$ & $180 \mu \mathrm{g} / \mathrm{ml}$ & $99.250 \pm 15.735$ \\
\hline 2 & 100 & $100 \mu \mathrm{g} / \mathrm{ml}$ & $100 \mu \mathrm{g} / \mathrm{ml}$ & $200 \mu \mathrm{g} / \mathrm{ml}$ & $100.591 \pm 11.991$ \\
\hline 3 & 120 & $100 \mu \mathrm{g} / \mathrm{ml}$ & $120 \mu \mathrm{g} / \mathrm{ml}$ & $220 \mu \mathrm{g} / \mathrm{ml}$ & $100.111 \pm 3.237$ \\
\hline \multicolumn{7}{|c|}{} & & Formoterol Fumarate Dihydrate & \%Recovery \pm SD (n=3) \\
\hline Nr. & $\%$ Spiked & Conc. Of Test & $\begin{array}{c}\text { Standard Conc. } \\
\text { Added }\end{array}$ & Total Conc. & $100.979 \pm 0.035$ \\
\hline 1 & 80 & $3 \mu \mathrm{g} / \mathrm{ml}$ & $2.4 \mu \mathrm{g} / \mathrm{ml}$ & $5.4 \mu \mathrm{g} / \mathrm{ml}$ & $100.461 \pm 1.215$ \\
\hline 2 & 100 & $3 \mu \mathrm{g} / \mathrm{ml}$ & $3 \mu \mathrm{g} / \mathrm{ml}$ & $6 \mu \mathrm{g} / \mathrm{ml}$ & $104.306 \pm 4.201$ \\
\hline 3 & 120 & $3 \mu \mathrm{g} / \mathrm{ml}$ & $3.6 \mu \mathrm{g} / \mathrm{ml}$ & $6.6 \mu \mathrm{g} / \mathrm{ml}$ & \\
\hline
\end{tabular}

\section{Robustness:}

The robustness of the developed RP-HPLC method was determined by DOE Approach. Here the method was tested for robustness by deliberately changing the chromatographic conditions such as; Flow Rate, Percentage ACN and pH of the mobile phase. In a 3 level Factorial Design of response surface methodology the RP-HPLC method was analysed for robustness. The responses taken by changing the above chromatographic conditions were; Retention Time (min), Area (mV. s) and Asymmetry Factor.

32 trials were taken based on the factorial design created using Design Experts, out of which the $12^{\text {th }}$ trial was the best trial having lowest asymmetry factor. This trail had a mobile phase $\mathrm{pH}$ of 4.5 , a flow rate of $1 \mathrm{ml} / \mathrm{min}$ and the percentage ACN was 70 . It was also noted that the $\%$ RSD values of the retention times of both drugs did not exceed 2 hence proving that even with small, deliberate variation in the critical parameters the method is robust.

From the contour plots (Figure 7 and 8) made using Design Experts it may be concluded that with the increase in the flow rate and the \%ACN there is an increase in the retention times as well as the area of the peaks of both the drugs. It may also be seen from Figure 9 that despite the small changes in the chromatographic conditions the asymmetry factor is less than 2 . 

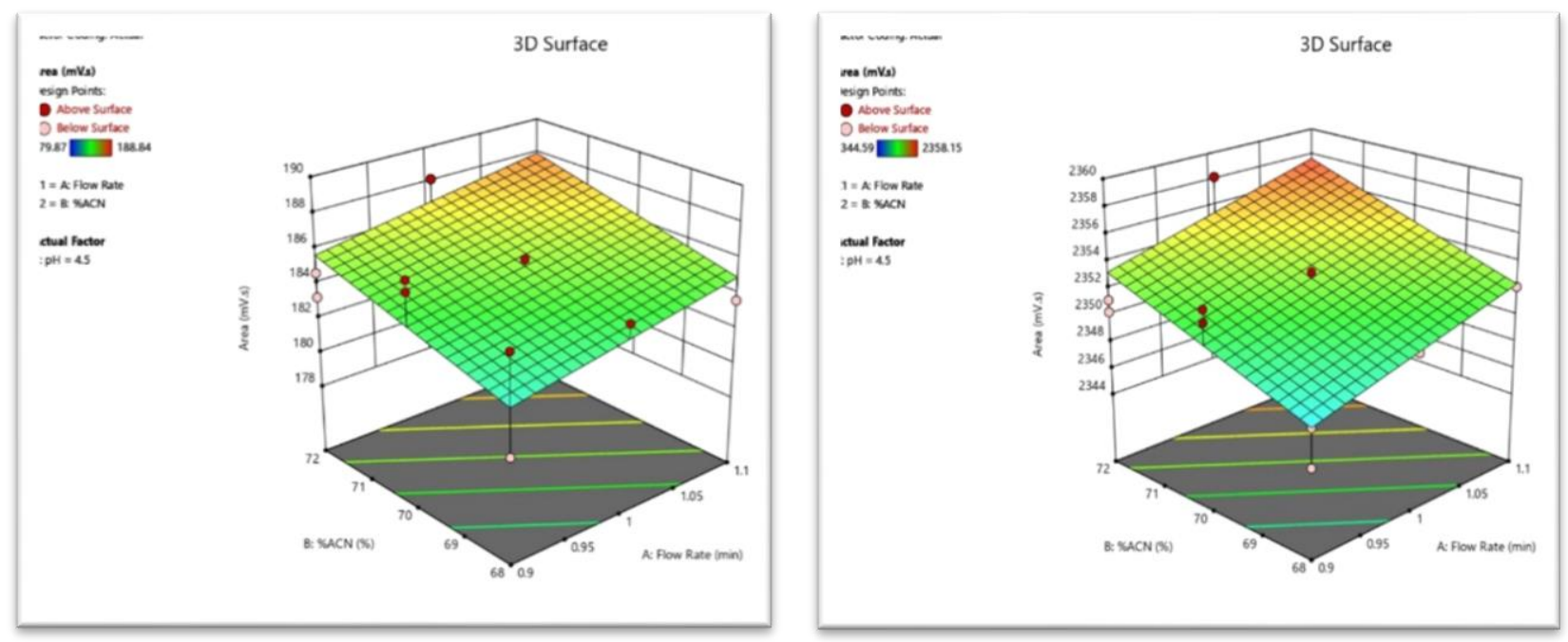

Figure 7: Contour plots of the areas of BDP (left) and FFD (right) with changes in flow rate and \%ACN
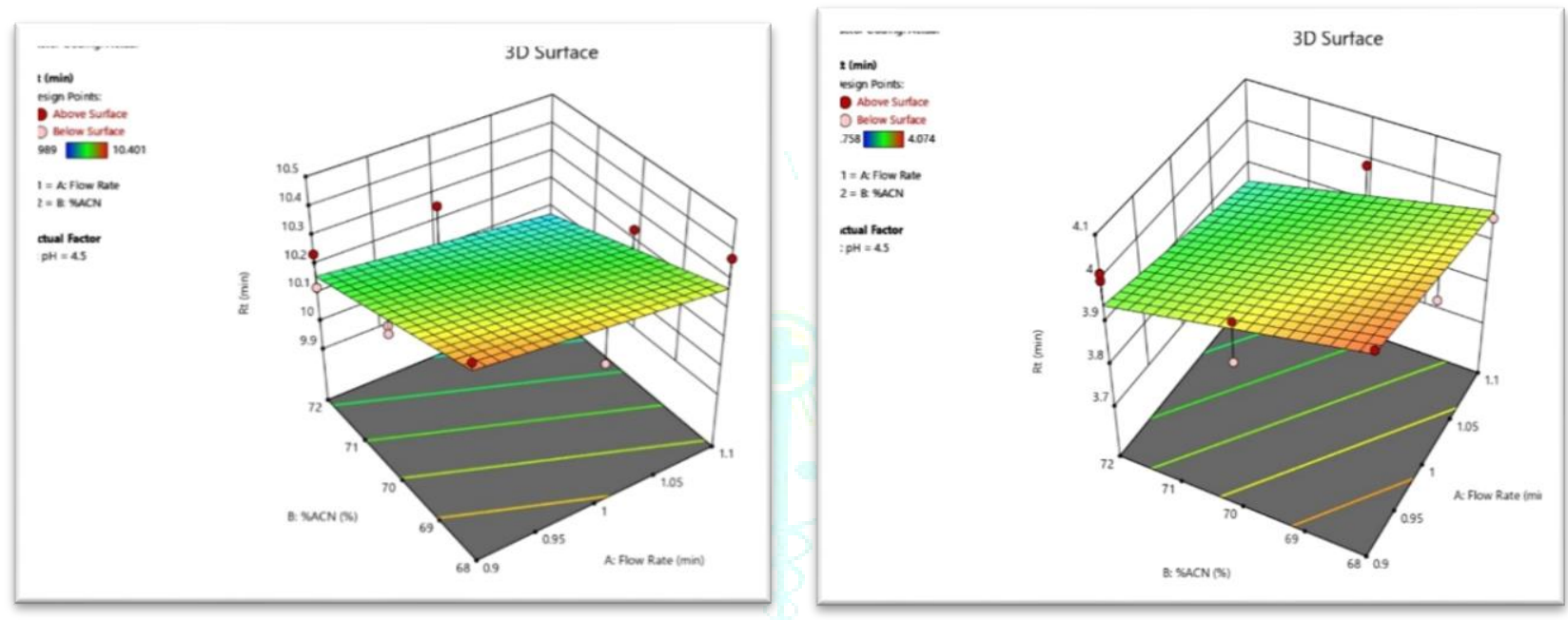

Figure 8: Contour plots of the retention times of BDP (left) and FFD (right) with changes in flow rate and \%ACN
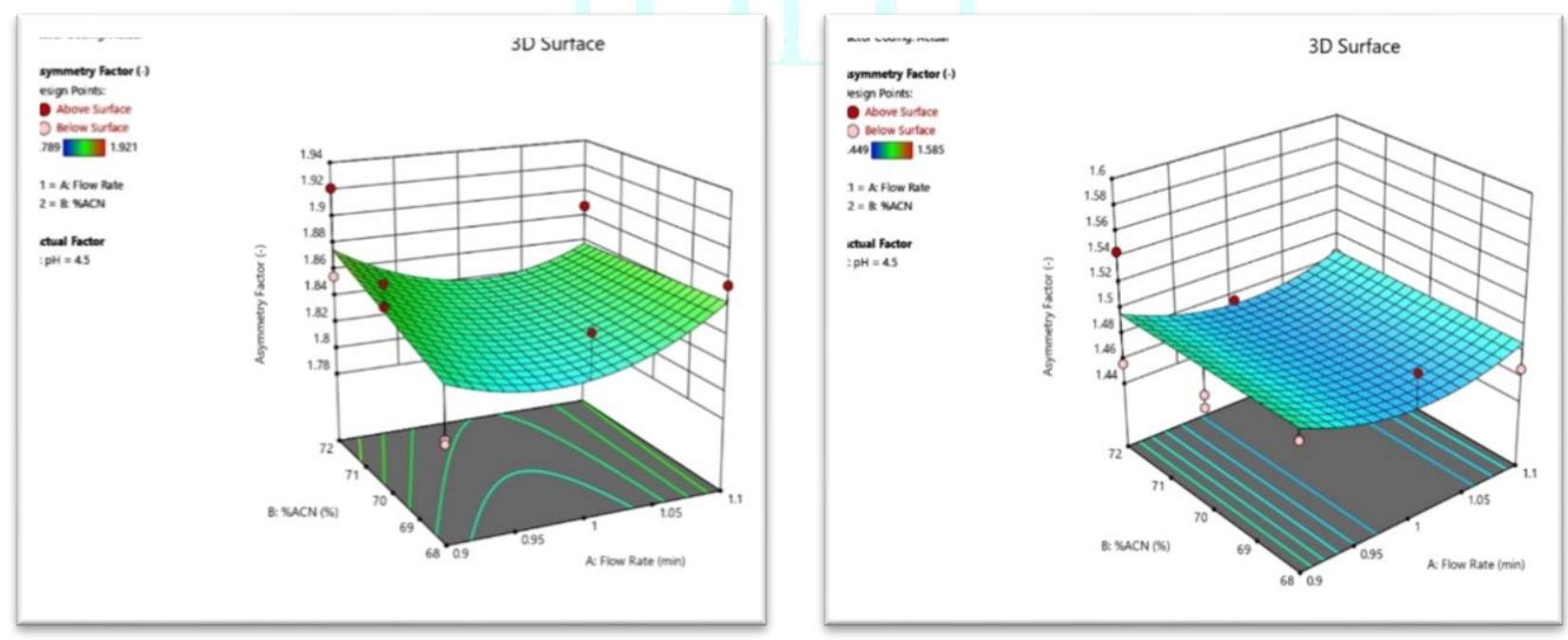

Figure 9: Contour plots of the asymmetry factors of BDP (left) and FFD (right) with changes in flow rate and \%ACN 


\section{Specificity:}

The specificity of the developed RP-HPLC method was done by injecting the following solutions into the HPLC system; Blank solution (Diluent used in the sample preparation), Standard drug solutions of both drugs (BDP and FFD) and Test solution (Formulation or Simulated mixture prepared in laboratory). It may be seen that there is no peaks in the blank solution as shown in Figure $\mathbf{1 0}$ which depicts that the diluent used in the sample preparation does not produce any interference during test measurement. Also as the Standard drug solutions peaks (shown in Figure 11) resemble that of the Test solution (shown in Figure 12) it can be concluded that the method is specific.

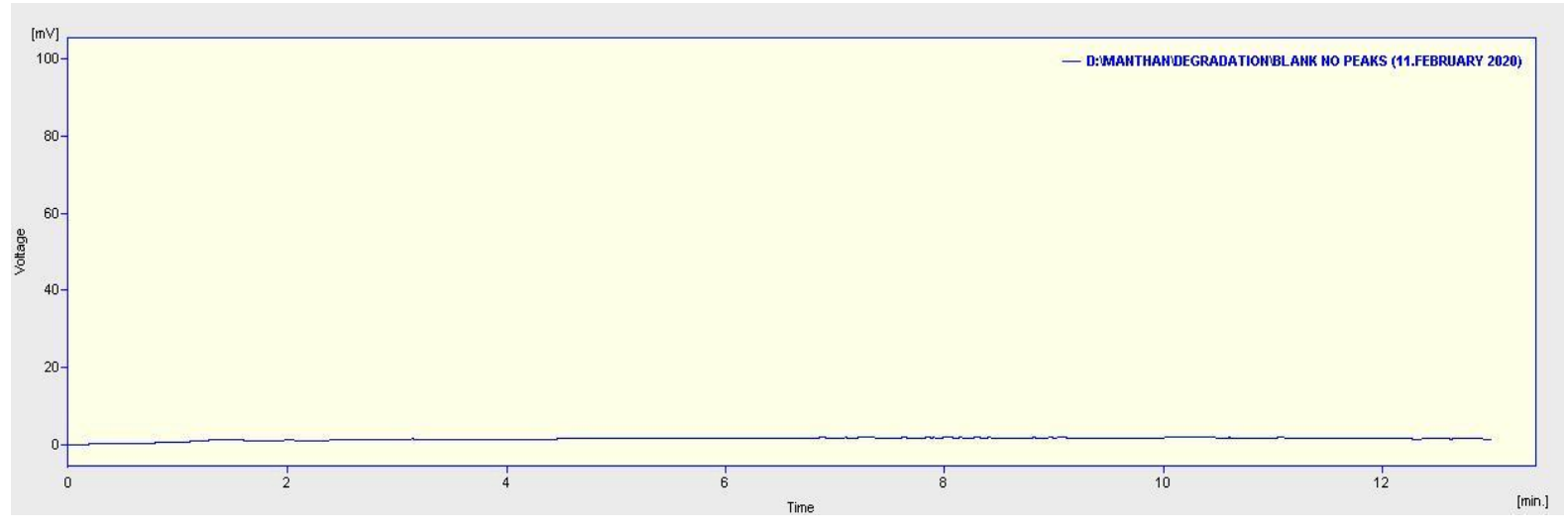

Figure 10: Chromatogram of the Blank solution (Diluent used in the sample preparation)

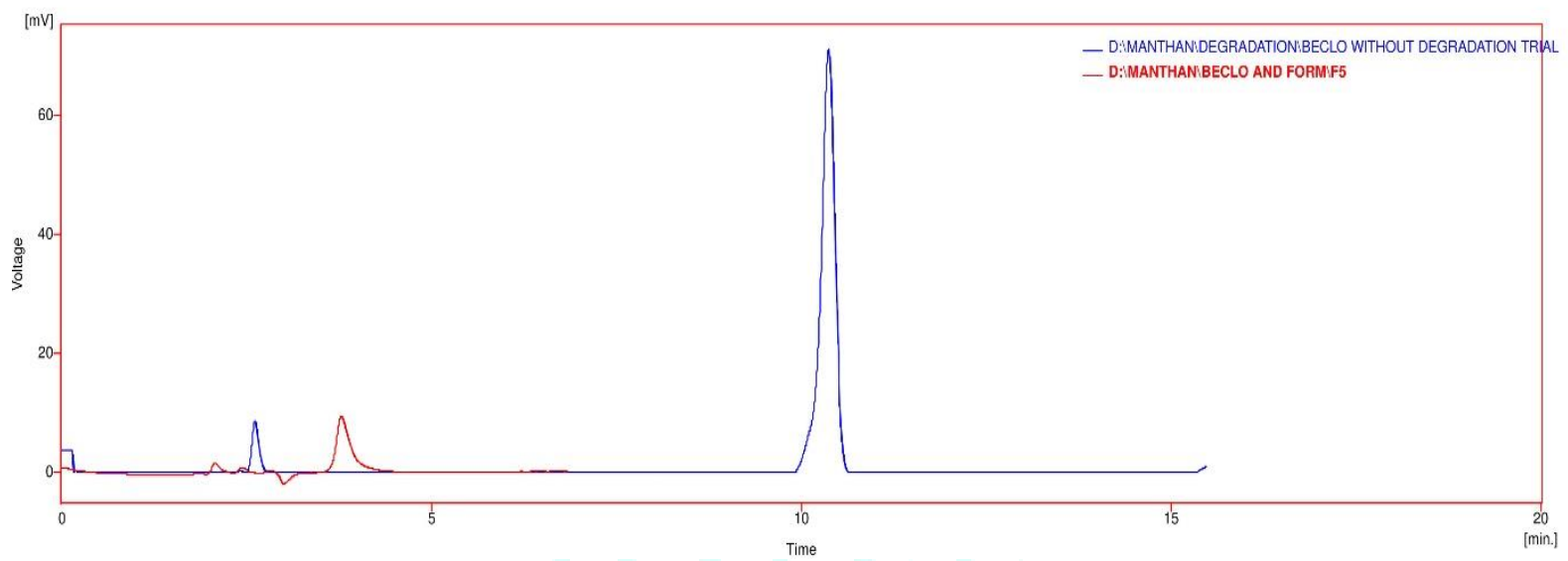

Figure 11: Chromatograms of the Standard drug solutions - API

(Blue - Beclomethasone Dipropionate, Red - Formoterol Fumarate Dihydrate)

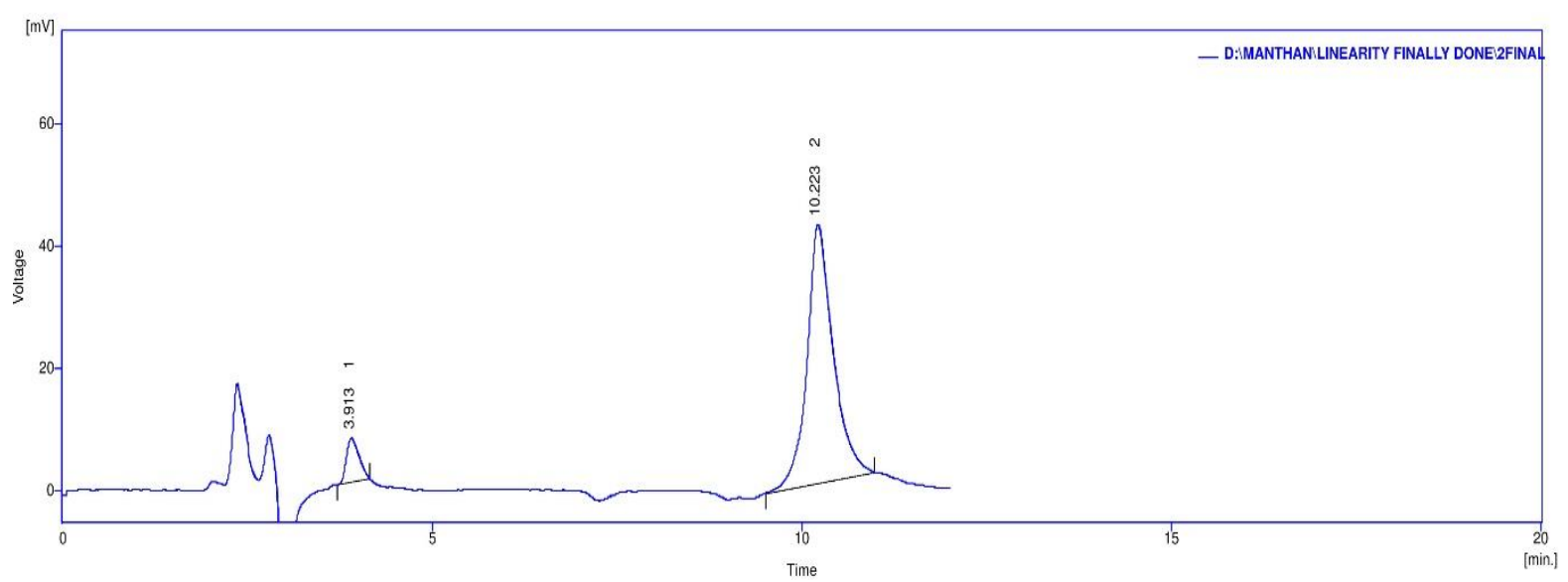

Figure 12: Chromatogram of the Test solution (Formulation) 


\section{System Suitability Testing for RP-HPLC:}

The system suitability tests which were applied for the RPHPLC Method were Retention Time, Theoretical Plates,
Asymmetry Factor, Area of the Peaks and Resolution between the peaks as shown in Table 8. Retention times of BDP and FFD as well as Resolution between the peaks were having a \%RSD value less than 2 .

Table 8: System suitability testing data representing the Retention Times, Theoretical Plates, Asymmetry Factor, Area of Peaks and Resolution of BDP and FFD

\begin{tabular}{|c|c|c|c|c|c|c|c|c|c|c|}
\hline \multicolumn{2}{|c|}{$\begin{array}{c}\text { Conc. } \\
(\boldsymbol{\mu g} / \mathbf{m l})\end{array}$} & \multicolumn{2}{c|}{$\begin{array}{c}\text { Retention Time } \\
\text { (min) }\end{array}$} & \multicolumn{2}{c|}{$\begin{array}{c}\text { Theoretical } \\
\text { Plates }\end{array}$} & \multicolumn{2}{c|}{$\begin{array}{c}\text { Asymmetry } \\
\text { Factor }\end{array}$} & \multicolumn{2}{c|}{$\begin{array}{c}\text { Area of Peaks } \\
\text { (mV. s) }\end{array}$} & \multirow{2}{*}{ Resolution } \\
\cline { 1 - 8 } BDP & FFD & BDP & FFD & BDP & FFD & BDP & FFD & BDP & FFD & \\
\hline 50 & 1.5 & 10.177 & 3.913 & 46837 & 24348 & 1.38 & 1.73 & 437.2 & 35.3 & 13.452 \\
\hline 100 & 3 & 10.223 & 3.913 & 48180 & 22698 & 1.42 & 1.70 & 1037.8 & 84.3 & 13.563 \\
\hline 150 & 4.5 & 10.223 & 3.913 & 45517 & 20520 & 1.67 & 1.85 & 1673.7 & 135.3 & 13.296 \\
\hline 200 & 6 & 10.190 & 3.907 & 47867 & 21138 & 1.78 & 1.44 & 2353.2 & 185.6 & 13.789 \\
\hline 250 & 7.5 & 10.177 & 3.907 & 48673 & 19793 & 1.39 & 1.79 & 2945.7 & 230 & 13.772 \\
\hline
\end{tabular}

\section{Comparison of the Methods}

\begin{tabular}{|c|c|c|c|}
\hline Parameters & Drug & $\begin{array}{c}\text { 1st Derivative } \\
\text { Method }\end{array}$ & $\begin{array}{c}\text { Dual Wavelength } \\
\text { Method }\end{array}$ \\
\hline \multirow{2}{*}{ Limit of Detection } & Beclomethasone Dipropionate & $0.739 \mu \mathrm{g} / \mathrm{ml}$ & $0.127 \mu \mathrm{g} / \mathrm{ml}$ \\
\cline { 2 - 4 } & Formoterol Fumarate Dihydrate & $0.183 \mu \mathrm{g} / \mathrm{ml}$ & $0.016 \mu \mathrm{g} / \mathrm{ml}$ \\
\hline \multirow{2}{*}{ Limit of Quantification } & Beclomethasone Dipropionate & $2.24 \mu \mathrm{g} / \mathrm{ml}$ & $0.384 \mu \mathrm{g} / \mathrm{ml}$ \\
\cline { 2 - 4 } & Formoterol Fumarate Dihydrate & $0.556 \mu \mathrm{g} / \mathrm{ml}$ & $0.049 \mu \mathrm{g} / \mathrm{ml}$ \\
\hline
\end{tabular}

\section{CONCLUSION}

A number of analytical methods are discussed in the given paper about the simultaneous estimation of Beclomethasone Dipropionate and Formoterol Fumarate Dihydrate in Bulk and in Pharmaceutical Formulations. Out of these methods, the Dual Wavelength Method is proposed to have a higher sensitivity as compared to the already existing methods to analyse this combination. A LC-MS compatible RP-HPLC method was also developed using $50 \mathrm{mM}$ Ammonium Acetate as the buffering agent in the aqueous part of the mobile phase, this method may be widely used for the estimation of this pharmaceutical combination.

\section{REFERENCES}

1. Liugino Calzetta, Maria Gabriella Matera, Francesco Facciolo, Mario Cazzola and Paolo Rogliani; Beclomethasone Dipropionate and Formoterol Fumarate Synergistically interact in hyperresponsive medium bronchi and small airways; Respiratory Research 2018; 19:65; 1-13

2. Parth D. Shah and Shailesh Koradia; Simultaneous determination of Beclomethasone Dipropionate and Formoterol Fumarate in Rotacap dosage form using two different spectrophotometric methods; World Journal of Pharmacy and Pharmaceutical Sciences 2014; 3 (5); 611-623

3. Vijaykumar K. Parmar, Hetvi N. Patel and Bhavin K. Patel; Sensitive and Robust method for simultaneous determination of Beclomethasone Dipropionate and Formoterol Fumarate Dihydrate in Rotacaps; Journal of Chromatographic Science 2014; 52; 1255-1266

4. D. De Orsi, L Gagliardi, F. Chimenti, and D. Tonelli; HPLC Determination of Beclomethasone Dipropionate and its degradation products in bulk drug and pharmaceutical formulations; Analytical Letters 2014 Taylor and Francis; 28:9, 1655-1663

5. A. Papi, P.L. Paggiaro; Beclomethasone/Formoterol versus Budesonide/Formoterol combination therapy in asthma; On behalf of the inhaled combination asthma treatment versus symbicort study group; Eur Respir J 2007; 29: 682-689

6. Beckett A.H, Stenlake J.B; UV-visible Spectrophotometry: Practical Pharmaceutical Chemistry; $4^{\text {th }}$ edition Part-II; C.B.S. Publishers, Delhi 2001; 285-97

7. ICH Harmonised Tripartite Guideline; Validation of Analytical Procedures: Text and Methodology Q2(R1); 1-13 